
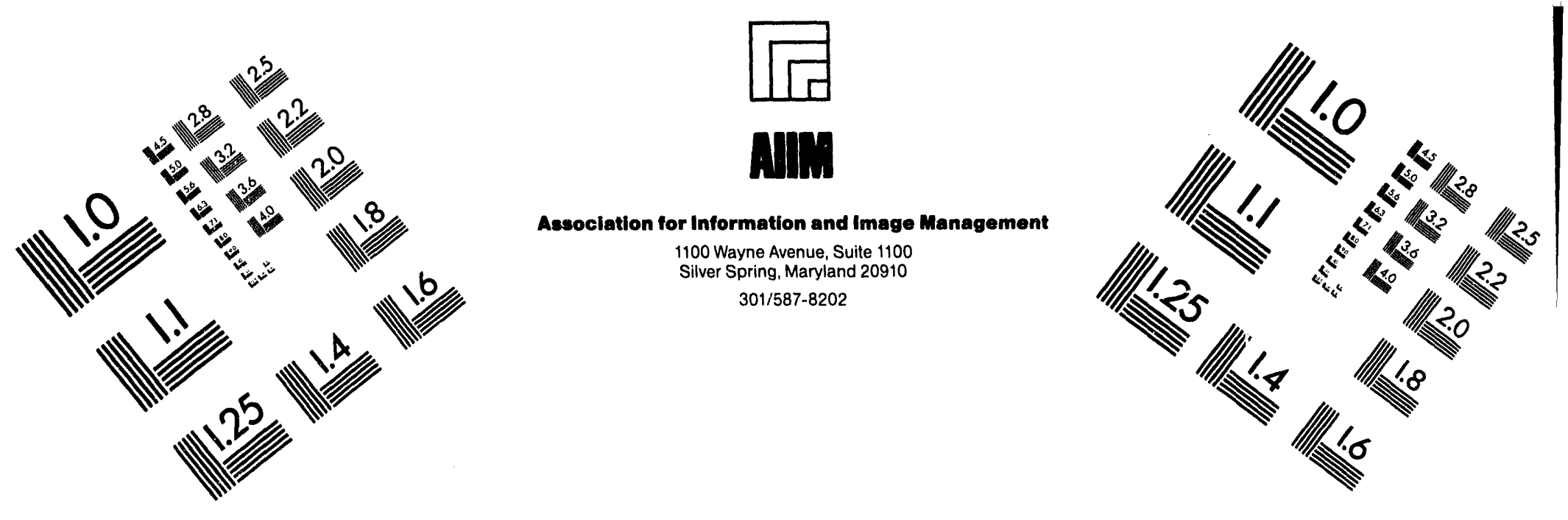

\title{
Centimeter
}

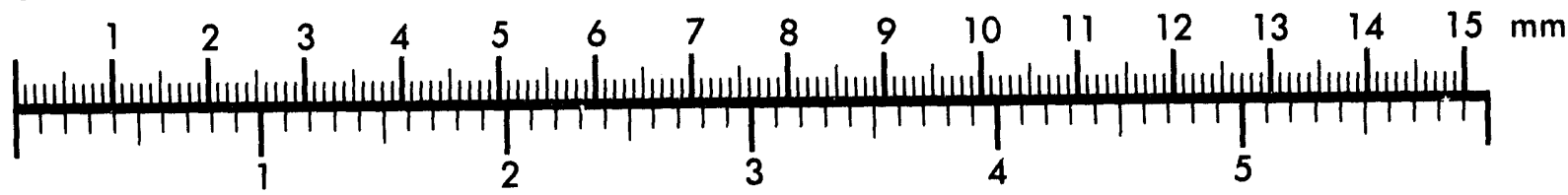
Inches
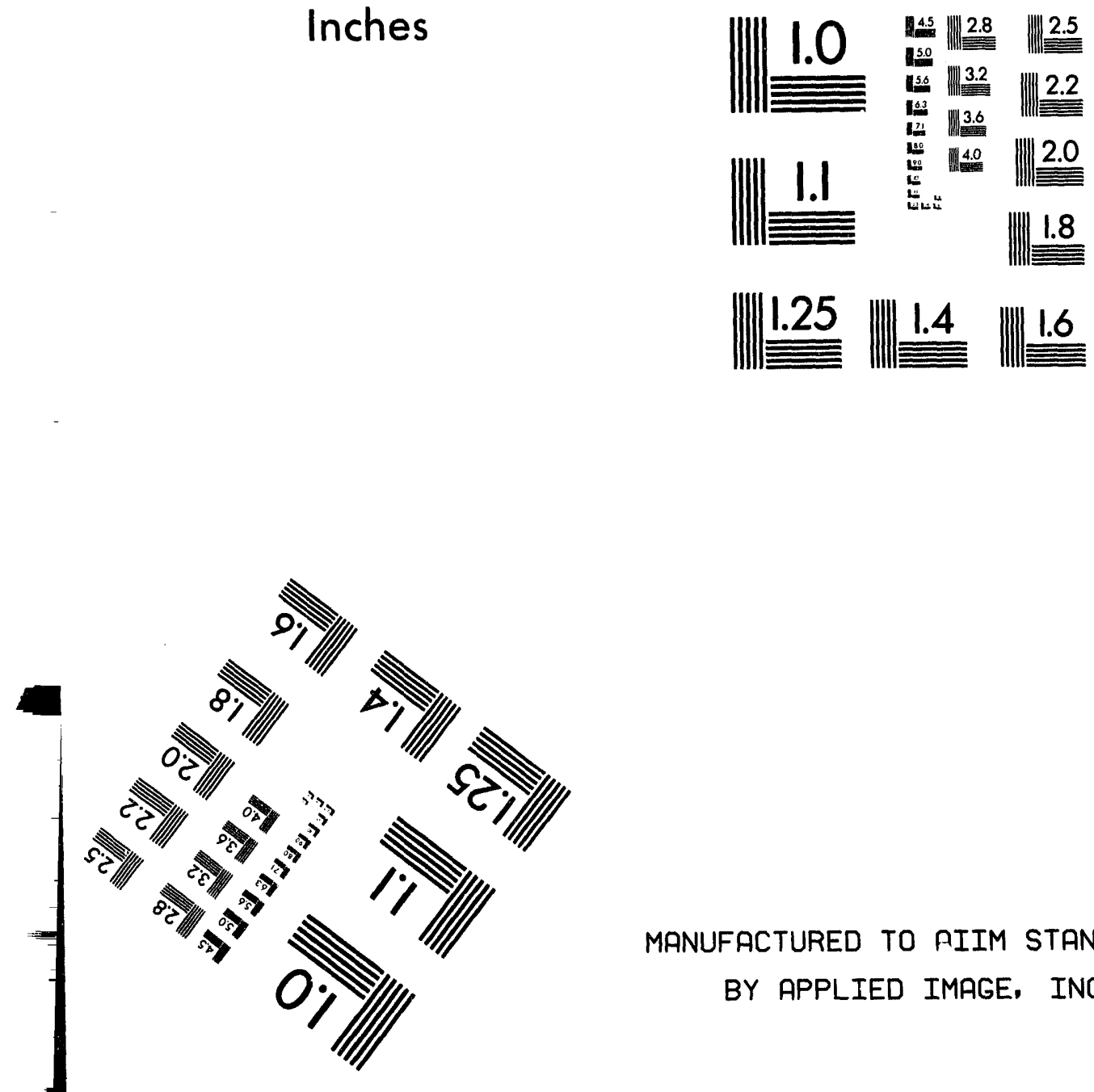

MANUFACTURED TO AIIM STANDARDS

BY APPLIED IMAGE, INC.

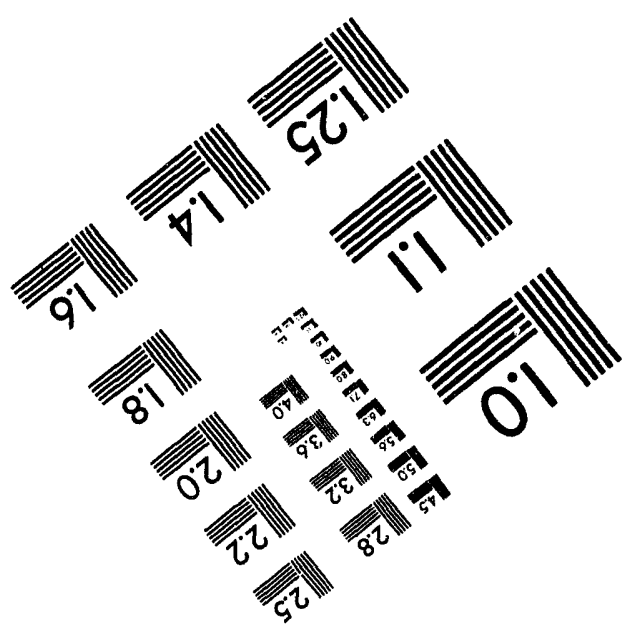



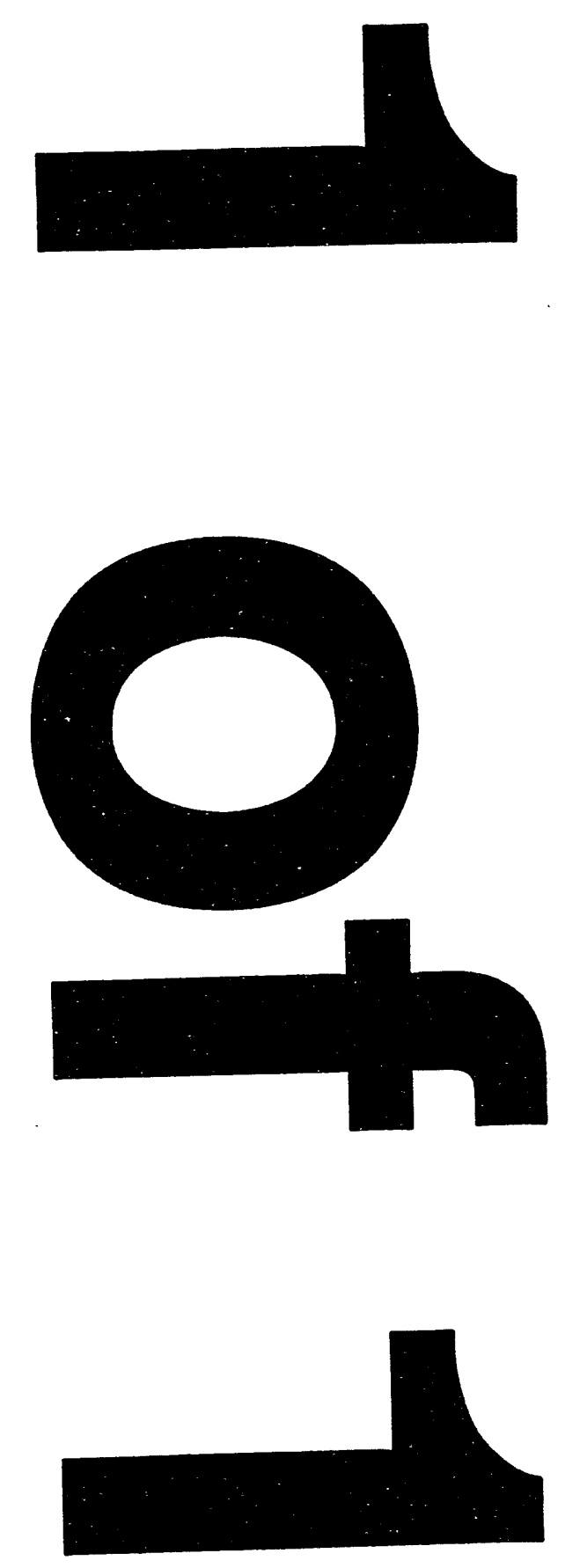


\title{
HEALTH SCIENCEŚ RESEARCH DIVISION
}

Environmental Restoration and Waste Management Non-Defense Programs (Activity No. EX 202001 0; ADS317AEX)

\section{Results of the Independent Verification Survey at the Old Betatron Building, Granite City, Illinois (GSG001)}

M. E. Murray and K. S. Brown

Date Issued - July 1994

Investigation Team

R. D. Foley-Measurement Applications and Development Manager

W. D. Cottrell - FUSRAP Project Director

M. E. Murray - Survey Team Leader

Survey Team Members

R. A. Mathis

D. D. McKinney

D. A. Rose

P. F. Tiner

Work performed by the

MEASUREMENT APPLICATIONS AND DEVELOPMENT GROUP

\author{
Prepared by the \\ OAK RIDGE NATIONAL LABORATORY \\ Oak Ridge, Tennessee 37831-6285 \\ managed by \\ MARTIN MARIETTA ENERGY SYSTEMS, INC. \\ for the \\ U. S. DBPARTMENT OF BNERGY \\ under contract DE-ACO5-84OR21400
}




\section{CONTENTS}

LIST OF TABLES $\ldots \ldots \ldots \ldots \ldots \ldots \ldots \ldots \ldots \ldots \ldots \ldots \ldots \ldots$

ACKNOWLEDGMENTS $\ldots \ldots \ldots \ldots \ldots \ldots \ldots \ldots \ldots \ldots \ldots \ldots \ldots$ vii

ABSTRACT $\ldots \ldots \ldots \ldots \ldots \ldots \ldots \ldots \ldots \ldots \ldots \ldots \ldots \ldots \ldots \ldots \ldots \ldots \ldots$

INTRODUCTION $\ldots \ldots \ldots \ldots \ldots \ldots \ldots \ldots \ldots \ldots \ldots \ldots \ldots \ldots \ldots$

SURVEY METHODS $\ldots \ldots \ldots \ldots \ldots \ldots \ldots \ldots \ldots \ldots \ldots \ldots \ldots$

SURVEY RESULTS $\ldots \ldots \ldots \ldots \ldots \ldots \ldots \ldots \ldots \ldots \ldots \ldots \ldots \ldots$

ORNL INDEPENDENT VERIFICATION SURVEY RESULTS . . . . . . . 2

REVIEW OF BNI VERIFICATION SURVEY RESULTS . . . . . . . . . 2

CONCLUSIONS $\ldots \ldots \ldots \ldots \ldots \ldots \ldots \ldots \ldots \ldots \ldots \ldots \ldots \ldots \ldots$

REFERENCES $\ldots \ldots \ldots \ldots \ldots \ldots \ldots \ldots \ldots \ldots \ldots \ldots \ldots \ldots \ldots \ldots$ 


\section{LIST OF TABLES}

1 Applicable guidelines for protection against radiation $\ldots \ldots \ldots \ldots \ldots \ldots \ldots$

2 Grid locations containing contamination levels above DOE guidelines at the Old Betatron Building, Granite City, Illinois .................. 6

3 Results of analysis of smears from the Old Betatron Building, Granite City,

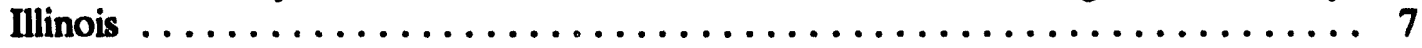

4 Results of detailed characterization at random locations at the Old Betatron Building, Granite City, Illinois $\ldots \ldots \ldots \ldots \ldots \ldots \ldots \ldots \ldots \ldots \ldots$

5 Post-remedial action survey results at the Old Betatron Building, Granite City, Illinois .................................... 10 


\section{ACKNOWLEDGMENTS}

This project was sponsored by the Office of Environmental Restoration, U.S. Department of Energy, under contract DE-AC05-840R21400 with Martin Marietta Energy Systems, Inc. The authors wish to acknowledge the contributions of W. D. Cottrell, V. P. Patania, D. A. Roberts, and J. Lovegrove of the Measurement Applications and Development Group, Oak Ridge National Laboratory, for participation in the analyses, editing, graphics, and reporting of data for this survey. 


\begin{abstract}
A team from the Measurement Applications and Development Group, Oak Ridge National Laboratory (ORNL), conducted an independent verification of the radiological condition of the Old Betatron Building, Granite City, Illinois, at the request of the Department of Energy in June of 1993. The building is owned by the National Steel Corporation. The contamination present resulted from the handling of uranium slabs of metal during the time the betatron facility was used to $x$-ray the slabs for metallurgical defects. The designation survey did not characterize the entire floor space because of obstructing equipment and debris. Therefore, prior to remediation by Bechtel National, Incorporated (BNI), a thorough characterization of the floor was conducted, and the results were immediately conveyed to on-site staff of BNI. An independent verification assessment was also performed after the cleanup activities were performed under the direction of BNI. The process of characterization, remediation, and verification was accomplished within a five-day period.
\end{abstract}

Based on results of the independent verification assessment, the Old Betatron Building was determined to meet the DOE radiological guidelines for unrestricted use. 


\section{Results of the Independent Verification Survey at the Old Betatron Building, Granite City, Illinois (GSG001)*}

\section{INTRODUCTION}

During the late 1950 s and early 1960 s, the General Steel Casting Corporation x-rayed uranium ingots for the Atomic Energy Commission (AEC) under purchase orders issued by Mallinckrodt Chemical Company. The facility used for this purpose is located at 1417 State Street (Parcel No. 301-001, Deed/Plat Book 19-24-14, Page 22-1, Madison County, Illinois) in southwest Granite City, Illinois, northeast of St. Louis, Missouri. Although purchase orders dated July 14,1961 , and others subsequent to that time are available, actual periods of operation are unknown. The facility was probably used on an as-needed basis.

Beginning June 7, 1993, a team from the Measurement Applications and Development Group, Oak Ridge National Laboratory (ORNL), conducted an independent verification of the radiological condition of the Old Betatron Building owned by the National Steel Corporation, at the request of the Department of Energy. The contamination present resulted from the handling of uranium slabs of metal during the time the betatron facility was being used to $x$-ray the slabs for metallurgical defects. The designation survey, reported in ORNL/RASA-89/10', did not characterize the entire floor space because of equipment and debris that could not be moved at the time. Therefore, prior to the remediation by Bechtel National, Incorporated (BNI), a thorough characterization of the floor was conducted and the results were immediately conveyed to BNI staff on-site. The independent verification assessment was performed by ORNL after the cleanup activities were performed under the direction of BNI. The process of characterization, remediation, and verification was accomplished within a five-day period.

Areas of known radioactive contamination were remediated by BNI while the characterization of the floor surface was in progress. The two known areas of radioactive contamination included a vacuum cleaner and a small section of ventilation duct.

\section{SURVEY METHODS}

A description of the typical survey methods and instrumentation providing guidance for the survey is given in Procedures Manual for the ORNL Radiological Survey Activities (RASA) Program, ORNL/TM-8600 (April 1987). ${ }^{2}$

The floor was characterized by marking it off in a one-meter grid (see Fig. 1) and completely scanning it for beta activity using large-area floor monitors and GM "pancake" ' detectors. Areas of radioactivity above background levels ${ }^{1}$ were marked for further

\footnotetext{
The survey was performed by members of the Measurement Applications and Development Group of the Health Sciences Research Division at Oak Ridge National Laboratory under DOE contract DE-AC05-84OR21400.
} 
characterization. All spots/areas with elevated activity were extensively characterized by determining the alpha and beta/gamma activity in $\mathrm{dpm} / 100 \mathrm{~cm}^{2}$. Smear samples were taken to determine the transferability of the activity. In addition, 31 of the 260 grid blocks were randomly selected and extensively characterized in the same manner as the elevated areas.

\section{SURVEY RESULTS}

Initially, spots in 12 grid blocks were determined to be above DOE guidelines (shown in Table 1) of $5000 \mathrm{dpm} / 100 \mathrm{~cm}^{2}$ (see Table 2), or marginally close enough to merit remediation. Two additional grid blocks were found to have contaminated spots in areas thought to be free of contamination. Table 2 gives the grid location of each contaminated spot. The contamination could best be described as spotty, with a maximum of 30,000 $\mathrm{dpm} / 100 \mathrm{~cm}^{2}$. Results of smear sample analysis (see Table 3) show the contamination was predominately fixed. The maximum alpha activity detected on a smear was $15 \mathrm{dpm} / 100 \mathrm{~cm}^{2}$, and no beta activity was detected above the minimum detectable activity.

The radiological survey results of the 31 randomly selected grid blocks are shown in Table 4. Results from the direct radiation measurement and the smear sample analysis were provided to the BNI on-site staff immediately after review by the ORNL project manager.

\section{ORNL INDEPENDENT VERIFICATION SURVEY RESULTS}

ORNL provided an independent verification of the radiological condition of remediated areas immediately after notification by BNI. Remediated areas were either cleaned to levels indistinguishable from background levels of radiation, as was usually the case, or cleaned to within DOE guidelines for surface contamination, even if detectable radiation above background remained. Table 5 contains the final verification survey data for all grid blocks where remediation occurred.

A few areas required multiple attempts at contamination removal/verification for two reasons. First, as the "hottest" spots were removed, less contaminated spots could be more readily identified. Secondly, different instruments and conversion factors among the contractors caused minor discrepancies. In each case, a mutual understanding between the contractors allowed for a quick turnaround in the overall process. The ALARA principle also influenced the decision to clean several spots to significantly less than DOE guidelines.

\section{REVIEW OF BNI VERIFICATION SURVEY RESULTS}

As a part of the Independent Verification Contractor (IVC) responsibilities, the verification survey results of the remediation contractor were reviewed. The verification survey results were transmitted by BNI to ORNL on July 14, 1993. The data package included: 
- Air Particulate Sample Reporting Log

- Gamma Exposure Rate Survey of Background and Betatron Room, Report No. 10693005

- Direct and Transferable Contamination Survey of Betatron Room (with maps), Report No(s). 10693002, 10693002-T, 10693003, 10693003-T

The verification survey results were reviewed for thoroughness and compliance with DOE requirements. The direct radiation measurements were also compared to the ORNL measurements conducted at the same locations. The results provided to ORNL appear to be thorough and accurate.

\section{CONCLUSIONS}

Based on the independent verification radiological survey by ORNL, and the review of the verification survey measurements by BNI, the Old Betatron Building meets the DOE guidelines for unrestricted use.

\section{REFERENCES}

1. W. D. Cottrell and R. F. Carrier, Results of the Radiological Survey at the Granite City Steel Facility, Granite City, Illinois, ORNL/RASA-89/10, Martin Marietta Energy Systems, Inc., Oak Ridge Natl. Lab., July 1990.

2. T. E. Myrick, B. A. Berven, W. D. Cottrell, W. A. Goldsmith, and F. F. Haywood, Procedures Manual for the ORNL Radiological Survey Activities (RASA) Program, ORNL/TM-8600, Martin Marietta Energy Systems, Inc., Oak Ridge Natl. Lab., April 1987. 
ORNL-DWG 94-5952
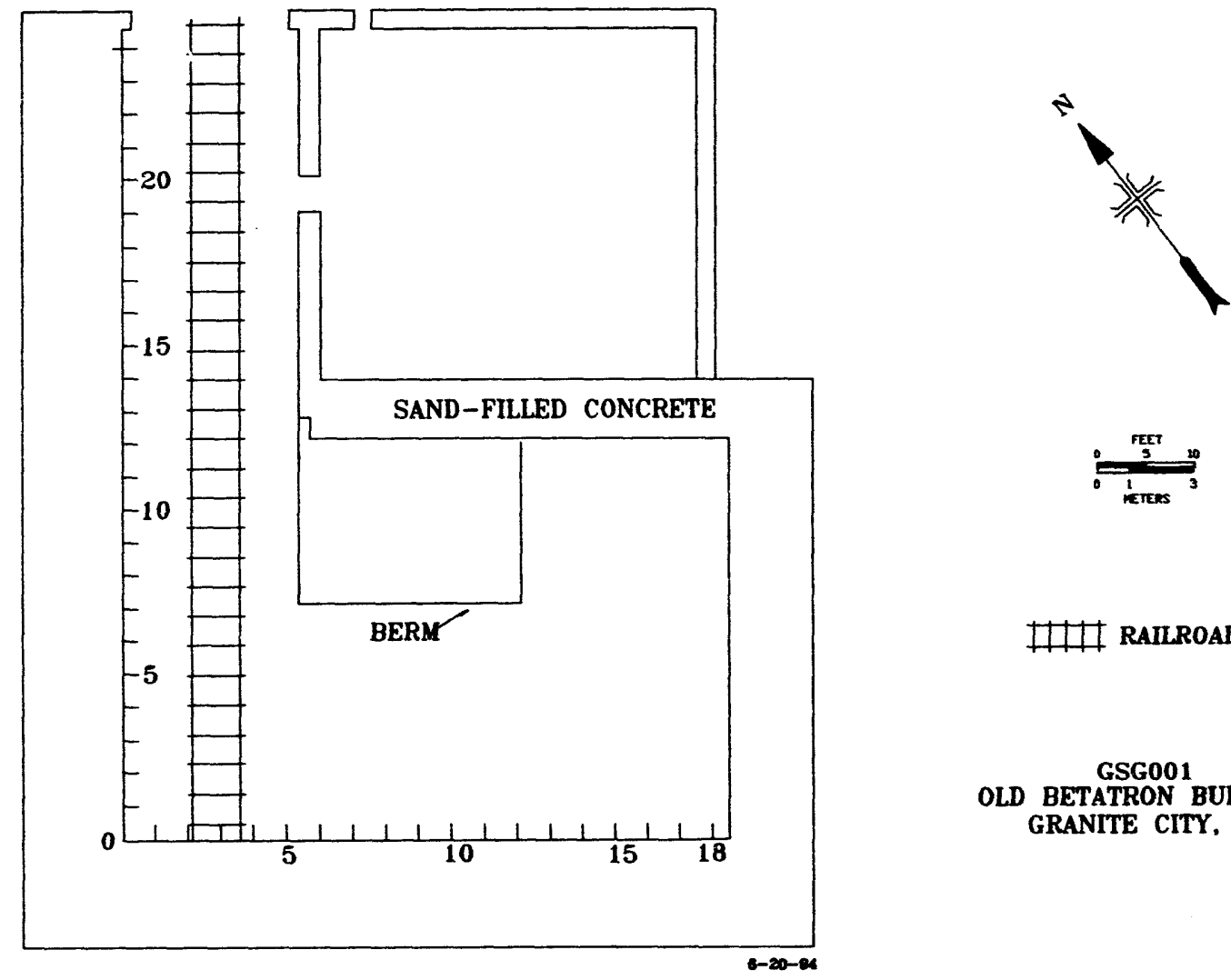

\#U RAILROAD

GSG001
OLD BETATRON BUILDING

GRANITE CITY, IL

Fig. 1. Ground-level floor plan of the Old Betatron Building Granite City, Ilinois. 
Table 1. Applicable guidelines for protection against radiation

(Limits for uncontrolled areas)

\begin{tabular}{lll}
\hline Mode of exposure & Exposure conditions & Guideline value \\
\hline $\begin{array}{l}\text { Total residual surface } \\
\text { Contamination }\end{array}$ & ${ }^{238} \mathrm{U}^{235} \mathrm{U}$, U-natural (alpha & \\
& emitters) & \\
& Maximum & $15,000 \mathrm{dpm} / 100 \mathrm{~cm}^{2}$ \\
& Average & $5,000 \mathrm{dpm} / 100 \mathrm{~cm}^{2}$ \\
& Removable & $1,000 \mathrm{dpm} / 100 \mathrm{~cm}^{2}$ \\
& & \\
\hline
\end{tabular}

'DOE surface contamination guidelines are consistent with NRC Guidelines for Decontamination at Facilities and Equipment Prior to Release for Unrestricted Use or Termination of Licenses for By-Product, Source, or Special Nuclear Material, May 1987.

Sources: Adapted from U.S. Department of Energy, DOE Order 5400.5, April 1990, and U.S. Department of Energy, Guidelines for Residual Radioactive Material at Formerly Utilized Sites Remedial Action Program and Remote Surplus Facilities Managument Program Sites, Rev. 2, March 1987; and U. S. Department of Energy Radiological Control Manual, DOE N 5480.6 (DOE/EH-256T), June 1992. 
Table 2 Grid locations containing contamination levels above DOE guidelincs at the Old Betatron Building, Granite City, Illinols

\begin{tabular}{|c|c|c|c|c|}
\hline \multicolumn{2}{|c|}{ Sample location } & \multicolumn{2}{|c|}{ Directly measured radiation levels } & \multirow{2}{*}{ Smear number ${ }^{b}$} \\
\hline North & East & $\begin{array}{c}\text { Alpha } \\
\left(\mathrm{dpm} / 100 \mathrm{~cm}^{2}\right)\end{array}$ & $\begin{array}{c}\text { Beta/gamma } \\
\left(\mathrm{dpm} / 100 \mathrm{~cm}^{2}\right)\end{array}$ & \\
\hline 8.70 & 16.35 & 77 & 6000 & 16 \\
\hline 8.80 & 16.10 & 511 & 10680 & 15 \\
\hline 8.80 & 16.75 & 161 & 6120 & 17 \\
\hline 8.90 & 16.75 & 161 & 7200 & 18 \\
\hline 9.50 & 17.55 & 231 & 5880 & 19 \\
\hline 9.50 & 17.80 & 266 & 5880 & 25 \\
\hline 9.60 & 3.90 & 28 & 6120 & 14 \\
\hline 10.00 & 17.55 & 455 & 6120 & 20 \\
\hline 10.25 & 16.35 & 280 & 7500 & 22 \\
\hline 10.40 & 16.15 & 224 & 17970 & 21 \\
\hline 10.60 & 4.00 & $<$ MDA & 12480 & 13 \\
\hline 11.00 & 18.20 & $<M D A$ & 7710 & 23 \\
\hline 11.25 & 15.30 & 28 & 4230 & 26 \\
\hline 12.30 & 4.00 & $<$ MDA & 6420 & 11 \\
\hline 12.70 & 4.10 & $<M D A$ & 6150 & 12 \\
\hline 13.20 & 4.15 & $<$ MDA & 7620 & 10 \\
\hline 14.60 & 3.80 & <MDA & 9930 & 8 \\
\hline 14.90 & 3.80 & $<\mathrm{MDA}$ & 7770 & 7 \\
\hline 15.10 & 3.80 & 35 & 30240 & 6 \\
\hline 15.30 & 3.80 & $<\mathrm{MDA}$ & 6840 & 4 \\
\hline 15.50 & 3.80 & $<$ MDA & 6270 & 5 \\
\hline 16.00 & 3.90 & $<M D A$ & 5970 & 3 \\
\hline 16.40 & 0.30 & $<$ MDA & 7620 & 9 \\
\hline 16.50 & 3.10 & $<$ MDA & 24540 & 1 \\
\hline 16.95 & 3.10 & $<\mathrm{MDA}$ & 10710 & 2 \\
\hline
\end{tabular}

'MDA $=50 \mathrm{dpm} / 100 \mathrm{~cm}^{2}$. Some alpha levels were below the MDA but above the critical decision level, indicating a measurable amount of alpha radiation above the instrument background.

bee Table 3 for analytical results. 
Tuble 3. Results of analyosis of smears from the Od Betatron Building. Granite City, Ilinois

\begin{tabular}{|c|c|c|c|c|c|}
\hline $\begin{array}{l}\text { Smear } \\
\text { number }\end{array}$ & $\begin{array}{c}\text { Alpha level" } \\
\left(\mathrm{dpm} / 100 \mathrm{~cm}^{2}\right)\end{array}$ & $\begin{array}{c}\text { Beta/gamma } \\
\text { level } \\
\left(\mathrm{dpm} / 100 \mathrm{~cm}^{2}\right)\end{array}$ & $\begin{array}{c}\text { Smear } \\
\text { number }\end{array}$ & $\begin{array}{c}\text { Alpha level } \\
\left(\mathrm{dpm} / 100 \mathrm{~cm}^{2}\right)\end{array}$ & $\begin{array}{l}\text { Beta/gamma level } \\
\left(\mathrm{dpm} / 100 \mathrm{~cm}^{2}\right)\end{array}$ \\
\hline 1 & $<M D A$ & $<\mathrm{MDA}$ & 41 & $<\mathrm{MDA}$ & $<\mathrm{MDA}$ \\
\hline 2 & $<$ MDA & $<$ MDA & 42 & 3 & $<$ MDA \\
\hline 3 & $<$ MDA & <MDA & 43 & 5 & $<$ MDA \\
\hline 4 & $<$ MDA & $<M D A$ & 44 & $<$ MDA & $<$ MDA \\
\hline 5 & $<$ MDA & $<\mathrm{MDA}$ & 45 & $<$ MDA & $<$ MDA \\
\hline 6 & $<M D A$ & $<M D A$ & 46 & 3 & $<M D A$ \\
\hline 7 & $<$ MDA & $<$ MDA & 47 & $<$ MDA & $<M D A$ \\
\hline 8 & $<M D A$ & $<$ MDA & 48 & $<$ MDA & $<$ MDA \\
\hline 9 & $<$ MDA & $<M D A$ & 49 & 3 & $<\mathrm{MDA}$ \\
\hline 10 & $<$ MDA & $<M D A$ & 50 & 8 & $<$ MDA \\
\hline 11 & $<$ MDA & $<$ MDA & 51 & $<M D A$ & $<$ MDA \\
\hline 12 & $<$ MDA & $<$ MDA & 52 & $<$ MDA & $<$ MDA \\
\hline 13 & $<$ MDA & $<$ MDA & 53 & $<$ MDA & $<$ MDA \\
\hline 14 & $<$ MDA & $<$ MDA & 54 & 3 & $<$ MDA \\
\hline 15 & $<$ MDA & $<$ MDA & 55 & $<$ MDA & $<$ MDA \\
\hline 16 & $<$ MDA & $<M D A$ & 56 & 3 & $<\mathrm{MDA}$ \\
\hline 17 & 13 & $<$ MDA & 57 & $<$ MDA & $<$ MDA \\
\hline 18 & $<$ MDA & $<$ MDA & 58 & $<$ MDA & $<\mathrm{MDA}$ \\
\hline 19 & $<$ MDA & $<$ MDA & 59 & $<$ MDA & $<$ MDA \\
\hline 20 & $<$ MDA & $<$ MDA & 60 & $<$ MDA & $<$ MDA \\
\hline 21 & $<M D A$ & $<$ MDA & 61 & 5 & $<M D A$ \\
\hline 22 & $<$ MDA & $<$ MDA & 62 & $<$ MDA & $<$ MDA \\
\hline 23 & 5 & $<M D A$ & 63 & $<M D A$ & $<M D A$ \\
\hline 24 & $<$ MDA & $<M D A$ & 64 & 15 & $<\mathrm{MDA}$ \\
\hline 25 & 3 & $<$ MDA & 65 & 5 & $<M D A$ \\
\hline 26 & 15 & $<$ MDA & 66 & $<$ MDA & $<\mathrm{MDA}$ \\
\hline 27 & $<$ MDA & $<$ MDA & 67 & $<$ MDA & $<M D A$ \\
\hline 28 & $<$ MDA & $<$ MDA & 68 & $<$ MDA & $<\mathrm{MDA}$ \\
\hline 29 & $<$ MDA & $<$ MDA & 69 & 5 & $<\mathrm{MDA}$ \\
\hline 30 & $<\mathrm{MDA}$ & $<\mathrm{MDA}$ & 70 & $<M D A$ & $<$ MDA \\
\hline 31 & $<M D A$ & $<M D A$ & 71 & $<M D A$ & $<$ MDA \\
\hline 32 & 3 & $<$ MDA & 72 & $<\mathrm{MDA}$ & $<$ MDA \\
\hline 33 & $<$ MDA & $<$ MDA & 73 & $<M D A$ & $<$ MDA \\
\hline 34 & 3 & $<M D A$ & 74 & 5 & $<M D A$ \\
\hline 35 & $<M D A$ & $<$ MDA & 75 & 8 & $<M D A$ \\
\hline 36 & 5 & $<$ MDA & 76 & $<$ MDA & $<\mathrm{MDA}$ \\
\hline 37 & $<$ MDA & $<\mathrm{MDA}$ & 77 & $<$ MDA & $<$ MDA \\
\hline 38 & $<$ MDA & $<$ MDA & 78 & $<$ MDA & $<M D A$ \\
\hline 39 & 3 & $<$ MDA & 79 & $<\mathrm{MDA}$ & $<\mathrm{MDA}$ \\
\hline 40 & $<$ MDA & $<$ MDA & & & \\
\hline
\end{tabular}

'MDA $=10 \mathrm{dpm} / 100 \mathrm{~cm}^{2}$. Some alpha levels were below the MDA but above the critical decisjon level, indicating a measurable amount of alpha radiation above the instrument background. $\mathrm{MDA}=120 \mathrm{dpm} / 100 \mathrm{~cm}^{2}$. 
Thble 4. Results of detailed characterization at raedom locations at the Old Betatron Building Granite City, Mlinois

\begin{tabular}{|c|c|c|c|c|}
\hline \multicolumn{2}{|c|}{ Sample location } & \multicolumn{2}{|c|}{ Directly measured radiation levels } & \multirow{2}{*}{ Smear number ${ }^{c}$} \\
\hline North & East & $\begin{array}{c}\text { Alpha } \\
\left(\mathrm{dpm} / 100 \mathrm{~cm}^{2}\right)\end{array}$ & $\begin{array}{l}\text { Beta/gamma } \\
\left(\mathrm{dpm} / 100 \mathrm{~cm}^{2}\right)\end{array}$ & \\
\hline 0.00 & 4.00 & $<$ MDA & 1020 & 28 \\
\hline 0.00 & 8.00 & $<$ MDA & $<$ MDA & 29 \\
\hline 0.00 & 14.00 & $<\mathrm{MDA}$ & $<$ MDA & 30 \\
\hline 1.00 & 6.00 & $<M D A$ & $<\mathrm{MDA}$ & 31 \\
\hline 1.00 & 10.00 & $<$ MDA & $<$ MDA & 32 \\
\hline 1.00 & 17.00 & $<M D A$ & $<$ MDA & 33 \\
\hline 2.00 & 2.00 & $<\mathrm{MDA}$ & 600 & 27 \\
\hline 2.00 & 4.00 & $<$ MDA & $<M D A$ & 34 \\
\hline 2.00 & 11.00 & 21 & $<\mathrm{MDA}$ & 35 \\
\hline 3.00 & 3.00 & $<$ MDA & $<M D A$ & 36 \\
\hline 3.00 & 7.00 & 35 & $<$ MDA & 37 \\
\hline 3.00 & 9.00 & $<\mathrm{MDA}$ & $<\mathrm{MDA}$ & 38 \\
\hline 4.00 & 12.00 & $<\mathrm{MDA}$ & 840 & 39 \\
\hline 4.00 & 15.00 & $<M D A$ & $<\mathrm{MDA}$ & 40 \\
\hline 5.00 & 6.00 & $<M D A$ & 540 & 41 \\
\hline 6.00 & 7.00 & $<\mathrm{MDA}$ & $<\mathrm{MDA}$ & 42 \\
\hline 6.00 & 10.00 & $<M D A$ & $<M D A$ & 43 \\
\hline 7.00 & 8.00 & $<$ MDA & $<M D A$ & 44 \\
\hline 7.00 & 13.00 & 35 & $<\mathrm{MDA}$ & 45 \\
\hline 7.00 & 17.00 & $<M D A$ & 720 & 46 \\
\hline 8.00 & 1.00 & $<$ MDA & 540 & 47 \\
\hline 9.00 & 5.00 & $<\mathrm{MDA}$ & $<M D A$ & 48 \\
\hline 9.00 & 14.00 & $<M D A$ & 750 & 49 \\
\hline 10.00 & 17.00 & 42 & 1200 & 50 \\
\hline 11.00 & 1.00 & $<\mathrm{MDA}$ & 1230 & 51 \\
\hline 14.00 & 5.00 & 28 & $<\mathrm{MDA}$ & 52 \\
\hline 18.00 & 3.00 & $<\mathrm{MDA}$ & 1080 & 53 \\
\hline 20.00 & 1.00 & $<M D A$ & $<M D A$ & 54 \\
\hline
\end{tabular}


Thble 4 (continued)

\begin{tabular}{ccccc}
\hline \multicolumn{2}{c}{ Sample location } & \multicolumn{2}{c}{ Directly measured radiation levels } & \\
\hline North & East & $\begin{array}{c}\text { Alpha } \\
\left(\mathrm{dpm} / 100 \mathrm{~cm}^{2}\right)\end{array}$ & $\begin{array}{c}\text { Beta/gamma } \\
\left(\mathrm{dpm} / 100 \mathrm{~cm}^{\mathrm{b}}\right)\end{array}$ & Smear number \\
\hline 21.00 & 3.00 & <MDA & 780 & 55 \\
21.00 & 5.00 & $<\mathrm{MDA}$ & $<\mathrm{MDA}$ & 56 \\
22.00 & 4.00 & <MDA & 570 & 57 \\
\hline
\end{tabular}

'MDA $=50 \mathrm{dpm} / 100 \mathrm{~cm}^{2}$. Some alpha ievels were below the MDA but above the critical decision level, indicating a measurable amount of alpha radiation above the instrument baskground.

bMDA $=500 \mathrm{dpm} / 100 \mathrm{~cm}^{2}$.

See Table 3 for analytical results. 
Table 5. Post-remedial action survey results at the

Old Betatron Building, Granite City, mlinois

\begin{tabular}{|c|c|c|c|c|}
\hline North & East & $\begin{array}{l}\text { Average direct beta } \\
\text { radiation levels } \\
\left(\mathrm{dpm} / 100 \mathrm{~cm}^{2}\right)\end{array}$ & Smear & number ${ }^{b}$ \\
\hline 8.00 & 15.00 & 1110 & & $\overline{64}$ \\
\hline 8.00 & 16.00 & 780 & & 63 \\
\hline 9.00 & 3.00 & 900 & & 69 \\
\hline 9.00 & 4.00 & 840 & & 68 \\
\hline 9.00 & 17.00 & 1140 & & 62 \\
\hline 10.00 & 3.00 & 600 & & 76 \\
\hline 10.00 & 4.00 & 780 & & 70 \\
\hline 10.00 & 16.00 & 990 & & 59 \\
\hline 10.00 & 17.00 & 1290 & & 58 \\
\hline 11.00 & 15.00 & 930 & & 60 \\
\hline 11.00 & 18.00 & 1830 & & 61 \\
\hline 12.00 & 3.00 & 900 & & 71 \\
\hline 12.00 & 4.00 & 1200 & & 72 \\
\hline 13.00 & 4.00 & 780 & & 75 \\
\hline 14.00 & 3.00 & 660 & & 79 \\
\hline 14.00 & 4.00 & 600 & & 77 \\
\hline 15.00 & 2.00 & 1200 & & 73 \\
\hline 15.00 & 3.00 & 1200 & & 78 \\
\hline 15.00 & 4.00 & $<$ MDA & & 74 \\
\hline 16.00 & 0.00 & 720 & & 65 \\
\hline 16.00 & 2.00 & 930 & & 67 \\
\hline 16.00 & 3.00 & 1020 & & 66 \\
\hline
\end{tabular}

${ }^{2} \mathrm{MDA}=500 \mathrm{dpm} / 100 \mathrm{~cm}^{2}$.

bee Table 3 for analytical results. 
ORNL/RASA-94/2

\section{INTERNAL DISTRIBUTION}

1. B. A. Berven

2-4. K. J. Brown

5. R. F. Carrier

6. W. D. Cottrell

7. R. D. Foley

8. R. O. Hultgren

9. C. A. Johnson

10-14. M. E. Murray

15. P. T. Owen

16. D. A. Roberts
17. R. E. Rodriguez

18. R. E. Swaja

19. M. S. Uziel

20. J. K. Williams

21-22. Laboratory Records

23. Laboratory Records - RC

24 Central Research Library

25. ORNL Technical Lib., Y-12

26. ORNL Patent Section

27-32. MAD Records Center

\section{EXTERNAL DISTRIBUTION}

33. W. L. Beck, Oak Ridge Associated Universities, E,SH Division, Environmental Survey and Site Assessment Program, P.O. Box 117, Oak Ridge, TN 37831-0117

34. P. Doolittle, Booz-Allen \& Hamilton, Inc., 4330 East-West Highway, Bethesda, MD 20814

35. J. J. Fiore, Director, Office of Eastern Area Programs, Office of Environmental Restoration, U.S. Department of Energy, 4th Floor, 656 Quince Orchard Rd., Gaithersburg, MD 20878

36-41. R. R. Harbert, Bechtel National, Inc., FUSRAP Department, Oak Ridge Corporate Center, 151 Lafayette Drive, P.O. Box 350, Oak Ridge, TN 37831-0350

42-44. J. King, Science Applications International Corp., P.O. Box 2501, 301 Laboratory Road, Oak Ridge, TN 37831

45. L. K. Price, Director, Former Sites Restoration Division, Oak Ridge Field Office, U.S. Department of Energy, P.O. Box 2001, Oak Ridge, TN 37831-8723

46. J. W. Wagoner II, Director, Division of Off-Site Programs, Office of Eastern Area Programs, Office of Environmental Restoration, U.S. Department of Energy, 4th Floor, 656 Quince Orchard Rd., Gaithersburg, MD 20878

47-51. W. A. Williams, Designation and Certification Manager, Division of Off-Site Programs, Office of Eastern Area Programs, Office of Environmental Restoration, U.S. Department of Energy, 4th Floor, 656 Quince Orchard Rd., Gaithersburg, MD 20878

52-53. Office of Scientific and Technical Information, U.S. Department of Energy, P.O. Box 62, Oak Ridge, TN 37831 

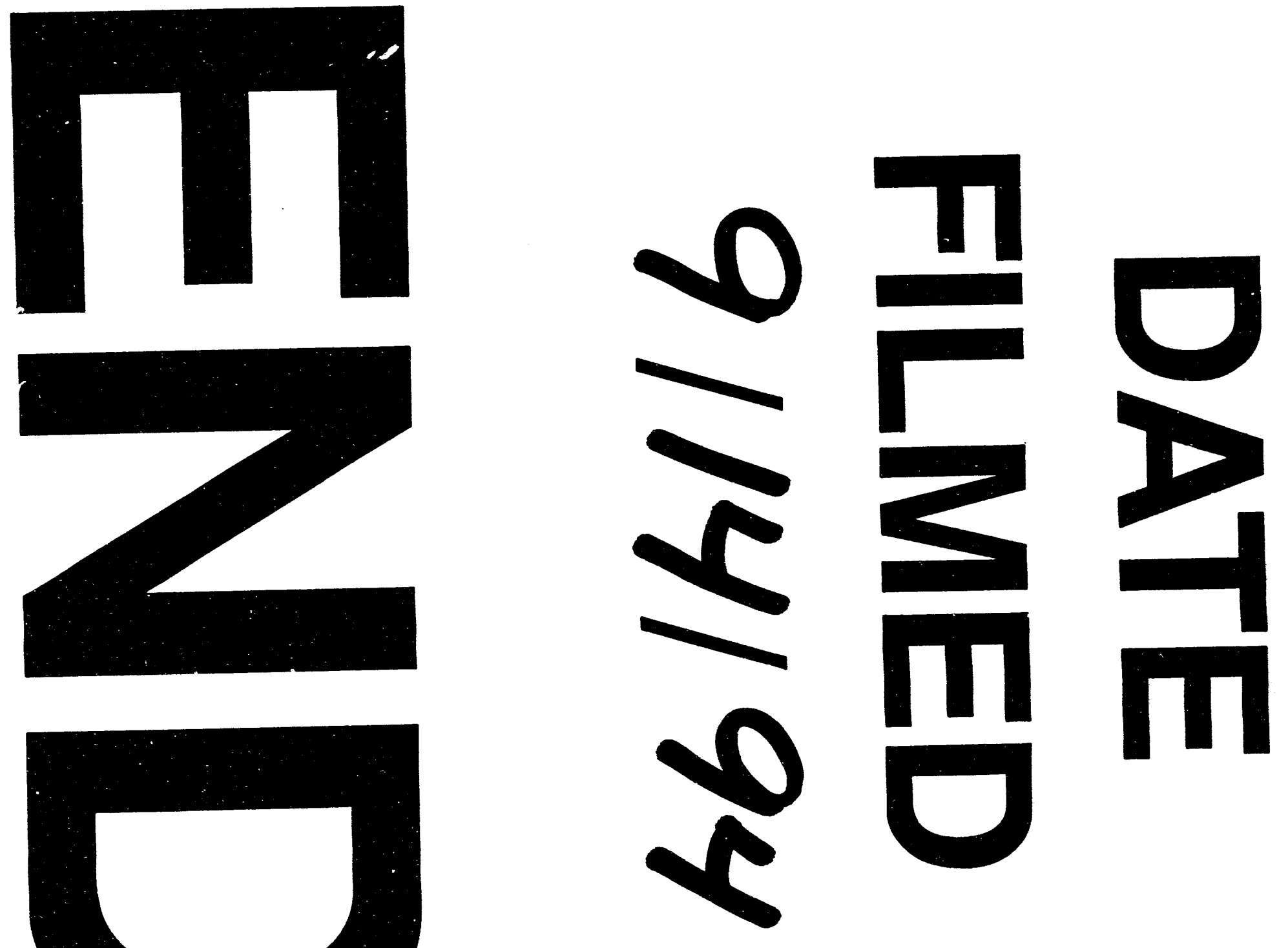
